\title{
Doctors v. government: a history of conflict
}

\section{Part I: Ontario government- physician showdown nothing new}

$\mathrm{T}$ he tweet appeared mid-morning. It bore news, not the good kind. Negotiations with the government had failed. A similar tweet soon followed, then another, and before noon a hashtag was born - \#CareNotCuts marking the start of an online campaign. Within hours, the Twitter stream, typically more of a Twitter trickle, swelled into a flood of infographics, statistics and warnings from unhappy doctors.

Untenable cuts to health care are coming. Patients will pay the price. Ignore government spin, support our campaign, add our Twibbon to your profile picture. So says the busier-than-ever Twitter feed of the Ontario Medical Association.

Contract negotiations over doctors' pay between the association and Ontario's Ministry of Health and Long-Term Care officially went kaput on Jan. 15. The last time these two parties went at it, in 2012, tensions also ran high, but they eventually reached a deal. Ontario is not the only province, of course, where money talks get testy between those who pay for medical services and those who provide them.

"The negotiations are always tough," says Kevin McNamara, former deputy minister of health for Nova Scotia. "But it's very hard to compare province to province because of all the different variables."

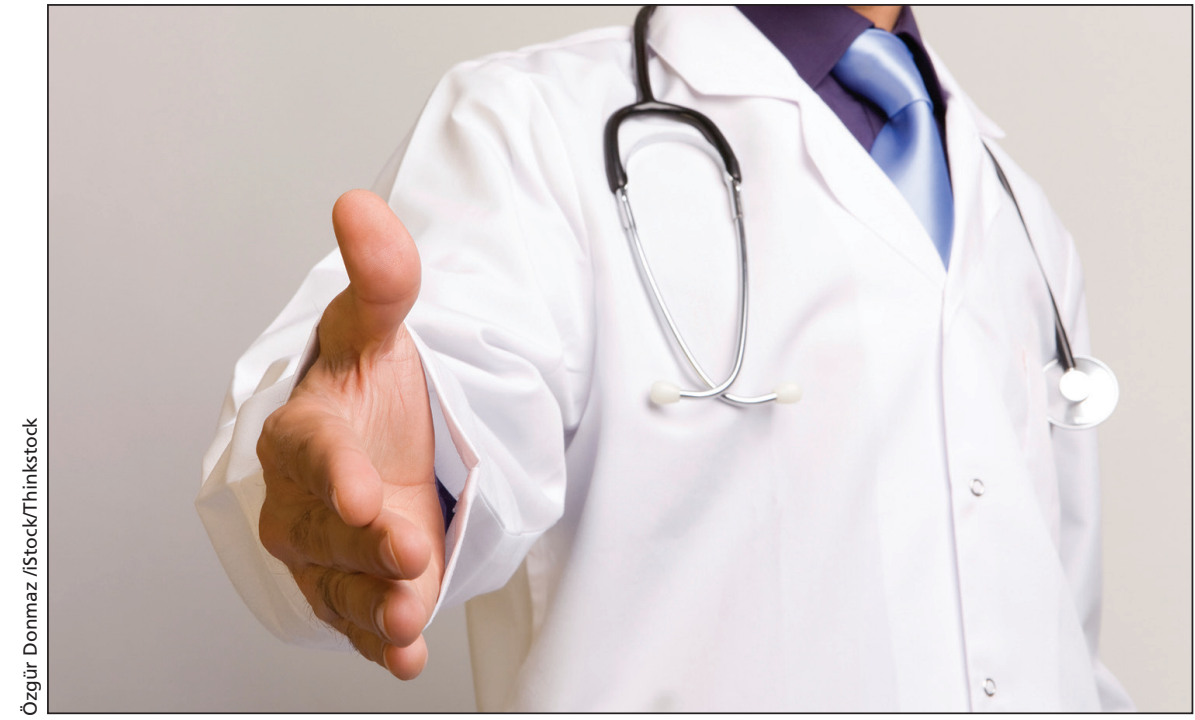

Closing a deal over pay between doctors and provincial governments is no easy task.

be well compensated. The way they are paid is also unique. Most often, doctors earn their living from fees for services rendered - they are contracted, not employed, by the government whereas the vast majority of working Canadians receive wages or salaries.

"Doctors belong to the only profession I know of where you can graduate from university, set up a practice, see as many patients as you want as often as you want, and send the bill to somebody and be guaranteed payment," says McNamara.

Gaining a clearer understanding of the nuances of the physician-government negotiation process can be difficult. In general, provincial health minis-

\section{Negotiations are the most contentious during times of fiscal restraint.}

The negotiations are also unique, unlike those between governments and teachers or other public servants, because physicians are a unique professional group. They enjoy higher levels of status, respect, trust, expertise and autonomy than most other professionals. Their services are vital, often complex and in ever-increasing demand. They receive far better pay than the average Canadian worker, and the public, in general, believes they deserve to ters tend to be tight-lipped about the process, the groups representing doctors even more so. Though the Ontario Medical Association is pushing its message hard on social media, that started only after negotiations failed. When $C M A J$ called Doctors Manitoba to comment on the subject, in what turned out to be a short conversation, a representative said the association does not comment on contract negotiations. Doctors of BC (British Columbia), on the other hand, was much more obliging, providing an insider to explain why the negotiations can be frustrating for doctors.

"Governments use the lever of 'You have an obligation to your patients and you can't withhold services. So no matter what your contention is around your fees or working conditions, get back to work. Otherwise we are going to call the college [College of Physicians and Surgeons of British Columbia] in and there will potentially be ramifications and penalties,"” says Dr. David Attwell, a family physician in Victoria and president of the statutory negotiating committee for Doctors of BC. "So that makes it very, very difficult for physicians in negotiations."

The negotiations are the most contentious during times of fiscal restraint. But they aren't always rancorous. There have been periods, when the economy is strong, during which governments offered little resistance to physician demands. Still, the history of physiciangovernment pay negotiations in Canada, overall, could hardly be described as boring. It did, after all, get off to a spectacularly terrible start. To revisit those inauspicious beginnings requires a trip to Saskatchewan circa July 1, 1962, shortly after midnight. — Roger Collier, CMAJ

CMAJ 2015. DOI:10.1503/cmaj.109-4986

Coming up: Part II: Where it all began 